\title{
Deforestation and Smallholder Income: Evidence from Remittances to Nepal
}

\author{
Man $\mathrm{Li}^{1}$, Wei Zhang ${ }^{2}$, Zhe Guo ${ }^{3}$, Prapti Bhandary ${ }^{4}$ \\ ${ }^{1}$ Assistant Professor, Department of Applied Economics, \\ Utah State University, Logan, UT 84322, USA \\ man.li@usu.edu \\ ORCiD: orcid.org/0000-0003-4296-4097 \\ Mailing: Department of Applied Economics, Utah State University, \\ 4835 Old Main Hill, Logan, UT 84322-4835, USA \\ ${ }^{2}$ Senior Research Fellow, International Food Policy Research Institute \\ Washington, DC 20005, USA \\ w.zhang@cigar.org \\ ORCiD: orcid.org/0000-0002-2933-6275 \\ Mailing: International Food Policy Research Institute, \\ 1201 Eye Street NW, Washington, DC 20005, USA \\ ${ }^{3}$ Senior GIS Coordinator, International Food Policy Research Institute \\ Washington, DC 20005, USA \\ z.guo@cigar.org \\ Mailing: International Food Policy Research Institute, \\ 1201 Eye Street NW, Washington, DC 20005, USA \\ ${ }^{4}$ Manager Project Support, Monitoring, and Evaluation, Conservation International \\ Arlington, VA 22202, USA \\ prapti6@gmail.com \\ Mailing: 2011 Crystal Dr., Suite 600, Arlington, VA 22202, USA
}




\title{
Deforestation and Smallholder Income: Evidence from Remittances to Nepal
}

\begin{abstract}
This article examines the effect of remittance income on deforestation in Nepal during 20012010 using satellite-based land use data and a nationwide household survey. Results indicate that remittance income reduced deforestation by 4.2 percentage points, accounting for almost $12 \%$ of deforestation during this period. An additional one-thousand-Rupee increase in average household annual remittance income reduced the ward-level deforestation by $\sim 0.435$ percentage points. There is no evidence that remittances induced expansion of agricultural land or stimulated demand for forest products. Instead, remittances contributed to the shift of households' demand for timber and fuelwood toward non-wood alternatives for housing construction and cooking. (JEL O13, Q23, O15)
\end{abstract}

Keywords: Deforestation, Remittances, Nepal, Smallholder income

Appendix materials can be accessed online at: https://uwpress.wisc.edu/journals/pdfs/LE-98-2Li-app.pdf 


\section{Introduction}

The impact of income increase on deforestation is indeterminate (Angelsen and Kaimowitz 1999; Zwane 2007; Alix-Garcia et al. 2013; among others). Multiple effects and causal pathways underlie this indetermination. Higher income can relax smallholder farmers' liquidity constraints, thereby increasing agricultural revenue via increasing inputs and investments; higher income also can increase demand for agricultural and forest products. Both effects can impose pressure on forestland. On the flip side, increased income can reduce pressure on forests, for example, by raising the opportunity cost of rural labor force or by replacing firewood with fossil fuels-based energy sources. How these forces interact in determining the income-deforestation relation is an empirical question. But scientific evidence is generally limited due to the endogeneity concerns about income growth. As poverty alleviation and environmental conservation have drawn considerable attention from academic scholars and policymakers, an improved understanding of the impact of income increase on forest resources and the underlying mechanisms is clearly needed. This study presents new evidence about this issue by focusing on remittance transfers and deforestation in Nepal.

Nepal is a landlocked country in the transitional zone between the eastern and western Himalayas. The country has rich forest resources and biodiversity: forests and shrubs together covered about 5.83 million hectares in the 1990 s, nearly $40 \%$ of the total land area of the country (DFRS 1999). The country had experienced rapid decline in forest stock in the 1980s and 1990s, with a reduction of about 1.7\% per annum (DFRS 1999). While the rate of deforestation had significantly slowed down since the late 1990s (FAOSTAT Database, accessed on July 6, 2016), partly due to the establishment of the community forestry program (Dahal and Chapagain 2008), there was still a considerable forest loss each year. Approximately 7,000 hectares of primary 
forests had been lost in Nepal during 2000-2005 (FAO 2006), making Nepal eighth among countries with the highest rate of deforestation of primary forests. Most of the cleared land was converted into agricultural use (Figure A1 in the Appendix). Fuelwood collection also added to deforestation. Solid biomass supplied $85 \%$ of the energy consumption in Nepal, 6.5 times as much as fossil fuels (WRI 2005). Rural residents, particularly the poor, relied on government forests to fill in a large supply gap of fuelwood left by community forests (Neupane 2003).

Deforestation coincided with a rapid increase of remittances to the country. Despite considerable progress on economic development in the last decade, poverty persisted with substantial rural-urban disparity (OPHI 2020). The Nepal Living Standards Survey (NLSS) conducted during 2010-2011 estimates total remittances as 259 billion NPR (about 2.61 billion USD), eight times as much as the total in 1995 in real terms. Of total remittances received by households, overseas remittances had grown from 55\% in 1995 to $80 \%$ in 2010. The proportion of households who received remittances had also increased from $23 \%$ to $56 \%$ during the same period. Among remittance-receiving households, about 27\%-35\% of their income was from remittances. The relatively large share of remittances as a source of rural income in Nepal, together with the rapid growth of overseas remittances to the country, provides an opportunity to study the impact of positive income shocks on deforestation.

This paper combines household survey and satellite-based land use data to empirically examine the impacts of remittances on deforestation at the ward level-the lowest administrative unit under village development committees (VDCs) or municipalities in Nepal—in the 20012010 decade. Land use data for two years, 2001 and 2010, were derived from the United States Geological Survey (USGS) Landsat Mapper/Enhanced Thematic Mapper (TM/ETM) scenes with a spatial resolution of 30 meters (Guo et al. 2015). The structure of the two-period data 
allows us to identify the location of deforestation. The land use data are merged with 3,912 household-level observations in 326 wards from the NLSS conducted during 2003-2004 (hereafter NLSS 2003/04). The survey contains detailed questions about remittances, household demographics characteristics, housing information, and agricultural activities. Using the combined data set, we relate deforestation to remittances and investigate the possible channels through which remittances may affect smallholder farmers' behavior in land clearing.

This paper makes two contributions to the literature. First, the rapid growth of overseas remittances to Nepal creates a source of income variation, which differs from income variation determined within the local economy. Previous empirical research on developing countries associates income growth with forest cover change (Capistrano and Kiker 1995; Barbier and Burgess 1996; among others). But most evidence addresses association rather than causality due to the limitation of data and methodology (see more discussion in Angelsen and Kaimowitz 1999 and Alix-Garcia et al. 2013). Rates of deforestation can be influenced by multiple factors, such as population growth, road construction, agricultural returns, and forest product prices (Li et al. 2015). These factors are plausibly confounding variables that influence both deforestation and local income, causing a spurious association. By focusing on remittance income which is relatively independent of the drivers of deforestation within a local economy, our identification of this relationship is less contested by the endogeneity challenge mentioned above.

Admittedly, remitting behavior occurs mostly within families and is one of the main outcomes of migration that is primarily determined locally. Analytical work on the impact of migration is inherently challenged by the possible endogeneity and selectivity involved in decisions surrounding migration (McKenzie and Sasin 2007; Massey Axinn, and Ghimire 2010), which naturally leads to a concern about potential endogeneity issue with remittances. This 
concern is likewise supported by the data. Half of the remittance senders surveyed in NLSS $2003 / 04$ were sons or daughters of recipients, $22 \%$ were spouses of recipients, and $11 \%$ were fathers or mothers of recipients. Young working-age males dominated the population of senders (88\%) with an average age of 33 years old. We seek to tackle this endogeneity issue by instrumenting remittances with exchange rate shocks while controlling for migration. NLSS 2003/04 suggests that $76 \%$ of the remittances Nepalis received were overseas remittances, primarily from nine countries. According to the International Monetary Fund (IMF) rates database (accessed on February 13, 2018), from 2000 to 2003, currencies of seven countries appreciated against the Nepalese rupee in a wide range of $3 \%$ to $48 \%$, whereas currencies of the other two countries depreciated by $10 \%$ and $17 \%$, respectively. These notable fluctuations in foreign exchange rates, together with a significant diversification of migration destinations emerging in the process of political and economic liberalization (Tiwari and Bhattarai 2011), provide a plausibly exogeneous source of variations in remittances.

Second, this paper emphasizes that, to formulate meaningful policy recommendations regarding poverty alleviation and conservation, it is crucial to understand the underlying mechanisms. In addition to examining the remittances-deforestation relationship in Nepal, we explore the household channels of the remittances effect. Most early studies on deforestation center on the identification of the causal relationship between deforestation and its potential drivers such as wage income and agricultural income (see a comprehensive review by Angelsen and Kaimowitz 1999). But the literature is less concerned with the effect of remittances on forest cover change, and is thin with respect to mediation analysis. In recent years, more systematic analysis of the underlying mechanisms has emerged (Alix-Garcia et al. 2013; Oldekop et al. 2018). In this paper, we examine whether and how remittance income affects agricultural outputs 
and usage of inputs (fertilizer, pesticides, improved seeds, irrigation, and hired labor) from the production side, as well as housing improvement and firewood collection from the consumption side. Our analysis therefore attempts to provide a comprehensive picture of the mechanisms underlying the impact of remittance income on deforestation in Nepal.

To put the remittances-deforestation relationship against a larger backdrop, the body of literature on forest transitions is relevant. Places experience forest transitions when declines in forest cover cease and recoveries in forest cover begin (Rudel 1998). Rudel et al. (2005) summarize that forest transitions have occurred in two, sometimes overlapping circumstances. In some places economic development has created enough non-farm jobs to pull farmers off their land, thereby inducing the spontaneous regeneration of forests in old fields, referred to as the “economic development path" to forest transitions. In other places a scarcity of forest products has prompted governments and landowners to plant trees in some fields, referred to as the "forest scarcity path." Moreover, the important role of smallholder farmers is highlighted in forest recovery through mechanisms such as sustainable agricultural intensification, migration, and remittances (Hecht 2010; Perfecto and Vandermeer 2010; among others). Whether the focus is on deforestation or forest transition, one thing is clear: the implications of migration and remittance economies are a central topic for scholars of immigration policy and transnational studies; yet very little research has focused on the empirical relationship of these monies to environment (Hecht 2010).

\section{Methods and Materials}

This section first discusses the relationship of deforestation, remittance, and migration. Then it describes the data sets used. Finally, it presents the empirical strategy for estimating the effect of remittance on deforestation. 


\section{Relationship between Deforestation, Remittance, and Migration}

Deforestation, especially when it is locally confined, closely relates to agricultural expansion. The microeconomics of deforestation has its theoretical root in the von Thünen's land rent approach, which assumes that land is allocated to the use with the highest rent and that agricultural-forest frontiers are where agricultural expansion is not profitable anymore. A survey of more than 140 economic models of deforestation finds a broad consensus that higher agricultural prices, lower transportation costs, lower rural wages, and shortage of off-farm employment opportunities are immediate causes of deforestation at the household or village level (Angelsen and Kaimowitz 1999).

Compared with those identified causes, the effect of remittances on deforestation is complex and remains understudied. On the one hand, use of remittances for consumption or production can affect smallholder farmers' decisions about whether to clear forests or not (Gray and Bilsborrow 2014; López-Feldman and Chávez 2017). On the other hand, remittances are one of the outcomes of out-migration which confounds with remittances to affect deforestation. Migration flows are considered important drivers of forest transitions and their effects on reducing deforestation and restoring forest are thought to be driven by a series of overlapping mechanisms (Hecht and Saatchi 2007; Kull, Ibrahim, and Meredith 2007; Oldekop et al. 2018). In some parts of the world, rural out-migration has contributed to a reduction in deforestation (Rudel 1998; Aide and Grau 2004). Out-migration can reduce population size and subsequently lower demands for agricultural and wood products. When migrants are working age population, migration can decrease agricultural labor force and thus release pressure on forests.

Meanwhile, migration and deforestation themselves are likely confounded. Rural land and labor markets are closely linked. Migration is costly; smallholder farmers may fund migration 
through felling trees and selling timber. If transaction cost associated with land market is high, households with limited land endowment may be more likely to migrate and these households also have incentives to deforest. Migration can be a strategy for escaping poverty, whereas deforestation is often linked to poverty. Moreover, poverty and household's non-remittance income and assets can influence the level of remittances, depending on how altruistic a sender is and whether the sender is motivated to maintain favor in the line of inheritance (e.g., Ilahi and Jafarey 1999; de la Brière et al. 2002). With a focus on Latin America, Radel et al. (2019) review research on how land change affects migration and how migration affects land systems, in particular, forest transitions, to conclude that the relationship is complex and highly contextspecific. The earlier expectation that out-migration from rural areas of Latin America would lead to widespread forest regrowth (Aide and Grau 2004) has not been observed in subsequent research (Aide et al. 2013).

The presence of other confounding factors such as natural or socioeconomic calamities, which concurrently influence all three variables (deforestation, migration, and remittances), further complicates the identification of the causal relationship of remittances and deforestation. Migration and remittances can be a risk-coping strategy to help households deal with risks of crop failure, price fluctuations, insecurity of land tenancy, livestock diseases, and so on (Katz and Stark 1986; Cox et al. 1998; Gray 2009). In most South Asian countries including Nepal, monsoon flooding-induced crop failure is not uncommon and can affect deforestation. Conflict is another potential confounder. From 1996 through 2006, more than 15,000 people were killed during the Nepalese Civil War, an armed conflict between the Communist Party of Nepal and the government of Nepal. The period 2002-2004 is the most intense years with about two-thirds of 
Civil War deaths (Human Rights Yearbooks, INSEC). Such a conflict may simultaneously affect forest clearings and migration behavior of smallholder farmers.

\section{Data}

This study relies on remote sensing-based land use data for two years (2001 and 2010) and a nationwide survey of 3,912 households from 326 wards, supplemented with ancillary data sets. Table A1 in the Appendix presents detailed data description and sources.

The land use data were developed by the International Food Policy Research Institute and the Center for Spatial Information Science and Systems, George Mason University, using USGS TM/ETM scenes (Guo et al. 2015). The team acquired 14 scenes of LandSat satellite series from the USGS's EarthExplore repository for 2001 and 2010 and used ISOData clustering and Support Vector Machine-supervised classification algorithm to develop the land use data at the 30-meter resolution. The data identify eight main land use classes in Nepal. The overall accuracy of land use classification is $83 \%$, validated with ground truth data collected by local collaborators from Nepal. This paper focuses on forestland, including broadleaf forests and needle forests. We define area deforested as the area of land that was covered by forests in 2001 but was cleared for other uses by 2010. Deforestation is measured by the rate of deforestation over the period 2001-2010 (i.e., total area deforested divided by total forest cover in 2001 in each ward).

The primary source of socioeconomic data is the second round of NLSS, a national integrated household survey conducted by the Central Bureau of Statistics (CBS) of Nepal from April 2003 to April 2004. The NLSS collected detailed information on the different aspects of household characteristics and welfare, including ethnicity, income, housing, education, and agricultural outputs and inputs during the past 12 months. To date, CBS has undertaken three 
rounds of NLSS respectively during 1995-1996, 2003-2004, and 2010-2011, among which the second one falls within the time window of this study. Sample size concern prevents us from using multiple rounds of NLSS. ${ }^{1}$

Following the methodology of the Living Standards Measurement Survey developed by the World Bank, CBS used a two-stage stratified sampling scheme to select a nationally representative sample for NLSS 2003/04. Specifically, the country was partitioned into six strata according to ecological zones and rural/urban classification. In each stratum, primary sampling units (PSUs) were selected by using probability-proportional-to-size sampling with the size measured by the number of households based on the 2001 Population Census of Nepal. Subsequently, 12 households were randomly selected within each PSU. The PSUs are mostly administrative wards of VDCs or municipalities. ${ }^{2}$ Our study restricts analysis to PSUs (hereafter called wards) at least partly covered by forests as of 2001. This restriction, together with missing data, yields a usable sample of 3,889 households from 281 wards for the empirical analysis. The probability-proportional-to-size sampling implies that a ward with a larger number of households is more likely to be chosen. We examine the representativeness of the NLSS sample for the rate of deforestation in a ward by comparing the empirical distribution of deforestation and the summary statistics between the NLSS sample and the statistical population of all wards in the country (see Appendix A1 for details on the comparison). We conclude that the stratified NLSS 2003/04 sample is representative for the rate of deforestation at the ward level.

We also use several ancillary data sets, including long-term rainfall and temperature data from the closest weather stations, conflict-related death toll during the most intense years of Nepal Civil War, the presence of the community forestry program, and exchange rates. Timeseries weather station data were collected from 277 national stations to calculate the median and 
the interquartile range (IQR), standardized by the median, of annual precipitation over the period 1990-2010. We use these two variables to proxy for the risks of flood-induced crop failure. The Informal Sector Service Centre, a leading human rights organization in Nepal, reports the number of people killed in each district from 1996 through 2006. We use the conflict-related death toll during 2002-2004-the most intense period during the Civil War-to measure the intense of conflict.

Data on the community forestry program drew from an up-to-date database of forest user group registrations, compiled by the Community Forestry Division, Department of Forest of Nepal. The database keeps detailed records, starting with 1988, of each forest user group; records include the village development committees and wards to which the group belongs, date of implementation, and involved area. Finally, we retrieved data on nominal exchange rates for selected currencies for the period 2000-2003 from the IMF rates database (accessed on February 13, 2018). We use the exchange rates, together with corresponding gross domestic product (GDP) deflators (IMF World Economic Outlook database, accessed on February 13, 2018), to calculate real exchange rates for the reported currencies in which remittances were made.

\section{Empirical Strategy}

We fit the cross-sectional data to the following equation to estimate the effect of remittances on deforestation:

$$
y_{i}=\beta_{0}+R_{i} \beta_{1}+M_{i} \beta_{2}+\mathbf{W}_{i} \boldsymbol{\beta}_{3}+\mathbf{X}_{i} \boldsymbol{\beta}_{4}+\varepsilon_{i}
$$

where $y_{i}$ represents the rate of deforestation in ward $i$ over the period 2001-2010; $R_{i}$ represents remittances received by all members of a household during the last 12 months prior to the survey interview, averaged across all sampled households in ward $i ; M_{i}$ represents estimated extent of migration averaged across all sampled households in a ward; $\mathbf{W}_{i}$ is a vector of ward-level factors 
or household characteristics averaged at the ward level that plausibly confound with remittances and/or migration to affect deforestation; $\mathbf{X}_{i}$ is a vector of other control variables; $\varepsilon_{i}$ is an error term. Table 1 reports summary statistics of all the variables used.

The vector $\mathbf{W}_{i}$ includes long-term median annual precipitation, long-term IQR of annual precipitation, conflict-related death toll, per capita land endowment (excluding people younger than 15 years old), CF program, caste groups (High/Dalits/Janajati), share of male headship, age of household head, and education of household head in years. The vector $\mathbf{X}_{i}$ includes logarithm of forest area in 2001 and ecological zone dummies. Here we only consider variables that may affect deforestation without causing serious endogeneity issues. Variables such as households' non-remittance income and community population may also impose pressure on forest clearing, but such variables are problematic because they could be either the result of deforestation or highly correlated unobserved factors in the error term.

Historically, flooding has been a more common stressor for Nepali farmers than drought, due to the heavy and erratic rainfall during the monsoon period. The long-term median and the IQR of annual precipitation (1990-2010) observed from the closest weather station from ward $i$ are used to proxy for risks in crop failure attributed to rainfall. We use conflict-related death toll to measure conflict intense and use per capita land endowment to measure the degree of land scarcity. $C F$ program is a binary variable indicating in any given ward whether or not at least one forest user group (FUG) registered for the community forestry program preceding the year 2001. Community forestry, introduced by the government in the early 1980s and reinforced by the Forest Act 1993, has handed over all the accessible national forests to the local people for their management and use (Kanel 2012), which can potentially influence deforestation in a 
community. We exclude FUGs registered after 2001 as those registrations may be the result of deforestation occurred during our study period.

Variables associated with household attributes capture the role of ethnic and demographic characteristics, which may affect family wealth, asset accumulation, and occupation. We use the shares of high caste, Janajati, and Dalits population in a ward to measure poverty, a potential driver of deforestation, migration, and remittances. Bennett, Dahal, and Govindasamy (2008) has found significant caste disparities in poverty and human development outcomes. Characterized by its hierarchical structure and hereditary basis, the Nepalese caste system stratified social classes and life chances of Nepalis over hundreds of years. NLSS 2003/04 records 80 ethnic groups from seven classes (NCBS 2003; Bennett, Dahal, and Govindasamy 2008). Among them, high caste (primarily Chhetri, Bahun, and Thakuri, 31.3\%), Janajati (indigenous people, 30.7\%), Dalits/low caste (untouchable, 11.7\%), and Newar (10.2\%) dominate the NLSS sample. We further grouped high caste and Newar together (hereafter, high caste). Composed of habitants of the Kathmandu Valley, Newar is an upper-ranking caste where people dominate the civil service and judiciary.

\section{Issues with Identification}

Of primary interest is the remittances variable $R_{i}$. Motivations to remit and the determinants of amount remitted are complex. One may expect that remittances are endogenous if variations in remittances primarily result from variations in out-migration and there are omitted variables affecting deforestation and out-migration simultaneously. We adopt the instrumental variable (IV) approach to address this endogeneity concern with two sequential specifications. ${ }^{3}$

We start with a parsimonious IV model, excluding migration $\left(M_{i}\right)$ and all explanatory variables $\left(\mathbf{W}_{i}\right)$ that are possibly correlated with migration. The empirical model is specified as: 


$$
\begin{aligned}
& y_{i}=\beta_{0}+R_{i} \beta_{1}+\mathbf{X}_{i} \boldsymbol{\beta}_{4}+\epsilon_{i}, \\
& R_{i}=\alpha_{0}+Z_{i} \alpha_{1}+\mathbf{X}_{i} \boldsymbol{\alpha}_{4}+\xi_{i},
\end{aligned}
$$

where $Z_{i}$ represents exchange rate shocks-the excluded instrument for remittances; $\mathbf{X}_{i}$ is defined the same way as in equation [1], serving as included instruments; $\epsilon_{i}$ and $\xi_{i}$ are error terms.

According to NLSS 2003/04, half the remittances senders were overseas migrant workers mostly dispersed across several Asian countries (Table 2). India was the largest single destination, with $32.1 \%$ of the total migrants. Saudi Arabia came in second with $5.5 \%$, followed by Malaysia and Qatar, with 3.5\% and 2.5\%, respectively. Other countries (or regions), including the United Arab Emirates, the United States, the United Kingdom, Hong Kong, Japan, and unreported countries, accounted for $5.7 \%$ of the total. Between 2000 and 2003, the currencies of most destination countries appreciated against the Nepalese rupee. For example, the currencies of the main Gulf countries (Saudi Arabia, the United Arab Emirates, and Qatar) rose 14.1\%-47.8\% in value against the Nepalese rupee and those of India and Malaysia rose by $2.9 \%$ and $10.8 \%$, respectively. Appreciation of foreign currencies was a positive income shock for an overseas migrant's origin family in Nepal—the greater the appreciation of the migrant's currency against the Nepalese rupee, the larger the amount of remittances in rupees the origin family received.

To construct the exchange rate shocks variable, we follow Yang's (2008) approach by first calculating exchange rate change $(E R C H)$ in percentage for each currency $j$ between the period 1999-2000 and the period 2002-2003:

$$
E R C H_{j}=\left(\frac{\text { Average currency exchange rate from Jan. } 2002 \text { to Dec. } 2003}{\text { Average currency exchange rate from Jan. } 1999 \text { to Dec. } 2000}-1\right) \times 100 \%,
$$

where exchange rate is measured in Nepalese rupees per unit of currency $j$ evaluated in the year 2000. We allow the starting period one year earlier than our study period to capture the time-lag 
effect of exchange rate effect on remittance sending. The exchange rate shocks variable is then constructed by averaging $E R C H_{j}$ across all currencies for each ward using a weighting factor computed as follows: the number of migrants from a ward to each country or region (including Nepal) divided by the total number of from the ward. ${ }^{4}$ Below we discuss the validity of exchange rate shocks as an instrument for the causal effect of remittances on deforestation based on the five assumptions proposed by Angrist, Imbens, and Rubin (1996); these assumptions constitute sufficient conditions for the identification of a meaningful causal inference.

Assumption 1: Stable unit treatment value assumption (SUTVA). Generally, deforestation in each ward is unrelated to the remittances received by households in other wards. One exception is that if a domestic migrant moves specifically to engage in land clearing activities, the rate of deforestation in the destination ward will increase. Since the migrant may send earnings back home, the assumption of independence between deforestation in the destination ward and remittances to the origin ward can be violated. Yet violation of SUTVA is not a major concern in our study because $48 \%$ of domestic migrants moved to urban areas and $78 \%$ worked in nonagricultural sectors, leaving only $10 \%$ of migrants engaged in agricultural activities in rural areas of Nepal. We empirically assess this assumption and find no evidence for violation of SUTVA (Table A5 in the Appendix).

Assumption 2: Random assignment of exchange rate shocks. The exchange rate approximately follows a random walk in the conventional literature of macroeconomics (Meese and Rogoff 1983; Moosa and Burns 2014; among others). Previous assessments of nominal exchange rate determination and forecasting changes in exchange rates established the stylized fact that it is extremely difficult to beat a random walk on a consistent basis (Chinn 2003). 
Assumption 3: Non-zero average causal effect of exchange rate shocks on remittances. This assumption requires that exchange rate shocks has strong explanatory power in explaining the variations of remittances (i.e., "strong" instrument), which is tested and confirmed in section 3.

Assumption 4: Monotonicity. This assumption implies that remittances must be a nondecreasing function of exchange rate shocks, which is likely to hold in the context of this study. Appreciation of foreign currencies in overseas migrants' destination countries will always increase the amount of remittances in rupees the origin family received, caeteris paribus. Even though migrants may reduce the remittances (in foreign currency) they had planned to send due to currency appreciation, the remittances in rupees received by their origin family should not be less than the amount when there is no currency appreciation (i.e., migrants have no incentive to send much less money under currency appreciation). Similar logic holds for the case of foreign currency depreciation in overseas migrants' destination country.

Assumption 5: Exclusion restriction. Exclusion restriction requires that the effect of exchange rate shocks on deforestation must be strictly via the effect of exchange rate shocks on remittances. It follows that holding remittances (and other covariates) fixed, the rate of deforestation in any individual ward would remain constant regardless of how exchange rates fluctuated. Because the exclusion restriction concerns counterfactuals that are never observed and is not directly verifiable from the data at hand, we assess the possibility of violation of this assumption by investigating two potential channels: i) the effect of exchange rate shocks on forestry and agricultural production and trade, and ii) the effect of exchange rate shocks on migration.

There is no evidence that appreciation of foreign currencies against Nepalese Rupee changed production of the major wood products - round wood and wood fuel-in Nepal. The annual 
production of the two products was quite stable over the period 2001-2010, in the ranges of 13.8 to 14.0 million cubic meters and 12.5 to 12.8 million cubic meters, respectively (FAO Forestry Production and Trade Database, accessed on June 26, 2018). The annual import and export quantities of these two products are negligible, accounting less than $0.0095 \%$ of production. Nor is there evidence that appreciation of foreign currencies affected the country's international trade of agricultural products. During 2001-2010, the annual import and export quantities of cereal (primary crops) erratically fluctuated in the range of 30 to 294 thousand metric tons and 2 to 54 thousand metric tons, respectively (FAOSTAT Database, assessed on January 31, 2021). The annual cereal net import accounts for only $0.33 \%-3.95 \%$ of production over this period.

As for the migration channel, the exclusive restriction implies that exchange rate shocks changes the amount of remittances but not the number of migrants. To verify this implication, we estimate the ward-level Pearson correlation coefficient between exchange rate shocks and migration, the latter being measured by the total number of migrants from a ward and the ratio of migrant numbers over household size, respectively. The two correlation estimates are close to zero and statistically insignificant ( $p$-values are 0.22 and 0.72 , respectively, see the upper panel of Table A3 in the Appendix). This result is in sharp contrast to the Pearson correlation coefficient between exchange rate shocks and remittances, which is estimated to be 0.455 at the $1 \%$ level of significance.

A further concern arising from the exclusive restriction assumption with respect to the migration channel is that exchange rate shocks may change the incentives to migrate after 2003. To preclude this possibility, we exploit the panel component of NLSS 2003/04 and NLSS 2010/11 to calculate changes in the two above-mentioned migration measures at the household level. The panel component contains 616 households in total. We calculate the exchange rate 
shocks using the number of migrants from a household surveyed in NLSS 2010/11 as the weighting factor. As anticipated, there is no significant correlation between exchange rate shocks and migration change, and their Pearson correlation coefficients are almost zero (see the lower panel of Table A3). This result is robust to alternative weighting factor of the number of migrants from a household surveyed in NLSS 2003/04.

Another underlying assumption is that the migration destination-based weighting factor is orthogonal to unobserved ward-specific determinants of deforestation. The rate of deforestation can be correlated with migration. But it is possible that this rate is uncorrelated with the selection of migration destination under certain circumstances. Whether to migrate and where to migrate are not the same decisions, though related. Historically, the primary reason for migration out of Nepal has been inadequate round-year employment in villages (Tiwari and Bhattarai 2011). While factors that drive the decisions on migration and on deforestation are not mutually exclusive, selection of migration destination is more likely to be influenced by migrants' and their origin families' social networks, as well as by the ethnicity/language/religion proximity of the destination in order to achieve economic success of their move (Montgomery 1991; Massey et al. 1993; Munshi 2003). To examine whether unobserved heterogeneity associated with the selection of migration destination preexists across wards, we estimate the ward-level Pearson correlation coefficients between the share of migrants to each country (i.e., migration destination-based weighting factor) and area in forest, area deforested, and the rate of deforestation, respectively. The correlation estimates for all countries except Malaysia are close to zero and statistically insignificant (see col. 1-3, panel A of Table A4 in the Appendix). We further calculate the Pearson correlation coefficient between the share of migrants to each country and the total number of migrants in each ward. Only the estimate for domestic migration 
is significantly negative at the $10 \%$ level while the estimates for other countries are statistically insignificant (see col. 4 in panel A of Table A4). This result confirms that whether to migrate and where to migrate are different decisions.

Therefore, we conclude that the exclusion restriction assumption of exchange rate shocks is unlikely to be violated in this study. There is no evidence that exchange rate shocks affect the annual production of major wood and agricultural products or the extent of migration in Nepal, nor evidence that selection of migration destination is correlated with deforestation. Among the five assumptions laid out above, monotonicity and exclusion restriction form the core of the IV approach. The higher the correlation between exchange rate shocks and remittances (i.e., the "stronger" the instrument), the smaller the bias from violations of the exclusion restriction and monotonicity assumptions (Angrist, Imbens, and Rubin 1996).

The proceeding discussion suggests that exchange rate shocks is plausibly a valid instrument for the causal effect of remittances on deforestation, we then extend the parsimonious IV model to a more comprehensive one by instrumenting both remittances and migration in equation [1]. The remittances and migration equations are respectively specified as:

$$
\begin{aligned}
& R_{i}=\alpha_{0}+Z_{i} \alpha_{1}+S_{i} \alpha_{2}+\mathbf{W}_{i} \boldsymbol{\alpha}_{3}+\mathbf{X}_{i} \boldsymbol{\alpha}_{4}+u_{i}, \\
& M_{i}=\alpha_{0}+Z_{i} \gamma_{1}+S_{i} \gamma_{2}+\mathbf{W}_{i} \boldsymbol{\gamma}_{3}+\mathbf{X}_{i} \boldsymbol{\gamma}_{4}+v_{i},
\end{aligned}
$$

where $S_{i}$ represents proportion of migrants to developed countries, an extra IV in addition to exchange rate shocks $Z_{i} ; \mathbf{W}_{i}$, and $\mathbf{X}_{i}$ are defined the same way as in equation [1]; $u_{i}$ and $v_{i}$ are error terms.

We calculate proportion of migrants to developed countries based on location of migrants reported in NLSS 2003/04, which indicates that $23 \%$ of overseas migrants moved to developed countries. As part of its liberalization reforms, Nepal gave freer rein to international migration. 
Since the mid-1990s, the central government of Nepal has removed restrictions on obtaining passports and visas required to seek overseas work outside India. The government has also entered a series of labor agreements with several fast-growing countries in the East and Southeast Asia such as South Korea and Malaysia and in the Gulf region such as Saudi Arabia, the United Arab Emirates, and Qatar (Tiwari and Bhattarai 2011). These reforms opened new destinations that were previously inaccessible to Nepali migrants. The Pearson correlation coefficient estimates reported in panel A of Table A4 supports the assumption that migration destination is exogenous to deforestation.

Thus far, we have discussed the validity of exchange rate shocks and proportion of migrants to developed countries from the perspective of institutional knowledge about remittances and migration. An additional instrument is preferred to further assess the exogeneity of these two IVs. Yet finding another good instrument that is uncorrelated with migration is practically difficult. In the absence of such IV candidates, we construct a variant of exchange rate shocks by replacing the ward-level weighting factor with the district-level weighting factor extracted from NLSS 1995/96 (i.e., the number of migrants from a district to a given country or region divided by the total number of migrants from that district). The district level is the most disaggregate level which allows us to combine the two rounds surveys (see footnote 1 for more details).

\section{Results}

To identify the effect of remittances on deforestation, we first focus on equation [1]. Since the rate of deforestation is bounded between zero and unity, we estimate equation [1] with fractional logistic regressions and use ordinary least squares (OLS) regression to examine whether the estimated remittance effect is sensitive to the nonlinear data nature. Fractional logit is chosen because it is relatively robust to the probability distribution of fractional response variables 
among other nonlinear regressions (Papke and Wooldridge 1996). We then use a two-stage logistic regression approach to separately estimate equations [2]-[3] and equations [1]-[4]-[5] to address the potential endogeneity issue. The advantage of the two-stage approach over the maximum likelihood-type method is that the former generally produces estimates not sensitive to model specification. This robustness is critical to the estimation of a deforestation model as deforestation may be driven by many forces.

\section{Do Remittances Affect Deforestation?}

Table 3 presents the results from the estimation of equation [1]. Column 1 corresponds to the most parsimonious version of ordinary fractional logistic model, which only includes remittances and the two control variables defined in $\mathbf{X}$. Column 2 reports the results from adding the migration variable. The specification of column 3 adds another eleven confounding variables defined in $\mathbf{W}$; most variables are exogenous to deforestation while migration is controlled for. The specification of column 4 excludes the migration variable from column 3. Columns 5 and 6 presents the results from logistic regressions where remittances are specified as a reduced form of migration. The last column reports the estimation results from OLS regression on deforestation.

The results in Table 3 can be summarized into several points. The rate of deforestation decreases with remittances at the significance level of $1 \%-5 \%$ across all logistic specifications, implying that the estimated remittance effect is robust to adding additional confounding variables. Quantitatively, the remittance effect obtained from the parsimonious equation (col. 1) is smaller in magnitude than those from the models that control for migration and other covariates (col. 2 and 3). Since the effects of remittances and migration on deforestation are mutually non-exclusive and the estimated remittance effect in column 1 is more inclusive, it can 
be plausibly argued that the negative effect of remittances on deforestation reported in column 3 is in part offset by a hypothetical positive effect of migration and the covariates $\mathbf{W}$, thereby resulting in a smaller net effect on deforestation as shown in column 1. As for the marginal effect, on average, an additional one-thousand-Rupee increase in household annual remittance income reduces the rate of deforestation by $0.299-0.450$ percentage points in a ward and the associated elasticity ranges between -0.077 and -0.117 , all else being equal.

There is no significant correlation between deforestation and migration. But one cannot simply attribute this statistical insignificance to the absence of causal relationship between the two variables. Rather, it is likely that the presence of extraneous forces counteracts the pressurereducing effect of migration on deforestation. As discussed in section 2, migration can be a riskabatement strategy for households and rural households may accelerate deforestation when they face risk of financial insecurity. Some other factors such as poverty, landholding, or fundraising for migration can also influence migration and deforestation in the same direction. Further investigation of how these effects act and interact in households' decision-making of migration is beyond the scope of this study. Nonetheless, migration affects deforestation through multiple channels, making its net impact statistically insignificant in the context of this study.

A comparison of migration estimates between the regressions that control for remittances (col. 2 and 3) and the reduced-form regressions (col. 5 and 6) provides insight into the complex migration-remittance-deforestation interlinkage from a different perspective. Purging migration effect of the remittance component substantially increases the coefficient estimate of migration. This comparison reconfirms the hypothetical negative effect of remittances on deforestation. Finally, inspection of column 7 and the rest columns provides a comparison of the OLS estimate with the estimated marginal effects in logistic models. The negative effect of remittances on 
deforestation obtained from the OLS regression is slightly smaller in magnitude and weaker in statistical significance than its logistic counterpart $(-0.410$ at the $10 \%$ level in col. 7 versus -0.450 at the $1 \%$ level in col. 3).

\section{Does the Potential Endogeneity Cause for Concern?}

To examine whether the potential endogeneity of remittance causes for concern to identify its causal effect on deforestation, we employ the IV approach to re-estimate the deforestation equation and report the estimation results in Table 4 . Columns 1a through $2 \mathrm{~b}$ present the point estimates from the parsimonious model (i.e., Eq. [2]-[3]) where the specification is exclusive of migration and the plausible confounding variables. Columns 3 a through $4 \mathrm{c}$ present the estimation results from the comprehensive model (i.e., Eq. [1]-[4]-[5]) in which migration is explicitly treated as an endogenous variable in addition to remittances while the confounding variables are controlled for.

Before turning to the variable of interest, it is useful to discuss the validity of the IVs used. Remittances expectedly increase with the ward- and district-level exchange rate shocks between 2000 and 2003 and with the proportion of migrants to developed countries at the significance level of $5 \%$ or better. These three IVs are "strong" instruments for remittances; the $F$ test of significance of instrument in the first-stage regression shows a value in the range of 39.3 to 110.6 (col. 1a, 2a, 3a, and 4a); much higher than the level of 10 typically recommended for rejecting weak instruments (Staiger and Stock 1997). In contrast, these instruments are weakly correlated with migration, with a joint $F$-statistic of 3.04 (col. 3b) and 2.19 (col. 4b), respectively. Among the three instruments, only the proportion of migrants to developed countries is significant at the $5 \%-10 \%$ level in the first-stage migration equation, whereas the other two instruments constructed from exchange rate shocks are statistically insignificant. While the associated point 
estimates must be interpreted with caution, these statistical tests reinforce the validity of exchange rate shocks to instrument for remittances in the parsimonious model, i.e., no correlation between exchange rate shocks and omitted migration effect.

Across the specifications, test of overidentifying restrictions supports the instrument exogeneity assumption. The $\mathrm{Wu}-\mathrm{Hausman}$ endogeneity test fails to reject the null hypothesis that remittances and migration are uncorrelated with the error term in the deforestation equation in both the parsimonious and the comprehensive models (the associated $p$-value is above the level of 0.84). Admittedly, the Wu-Hausman test is not always informative about endogeneity, depending on whether the model is properly specified and if the IVs are valid. Since it is not uncommon to fail to reject the null of the $\mathrm{Wu}-\mathrm{Hausman}$ test even when the IVs are good (in our case, the exchange rate shocks is plausibly a valid instrument for remittances), here we refrain from claiming exogeneity of remittances and report results from the IV models.

Turning to the remittance variable, its point estimates are robust to adding an additional instrument. These estimates are significantly negative with greater $p$-values than those from the ordinary logistic regressions presented in Table 3. The point estimates obtained from the parsimonious IV models are smaller in magnitude than their ordinary counterpart presented in column 1 of Table 3, and therefore more conservative. In contrast, the point estimates obtained from the comprehensive IV models are nearly identical to their ordinary counterpart reported in column 3 of Table 3 . This result suggests that controlling for migration and the confounding factors $\mathbf{W}$ helps purge the likely sources of bias and allows us to focus on the effect of remittances alone. The specification presented in columns $3 a-3 c$ of Table 4 (i.e., the comprehensive IV model) is thus the preferred model. In the present study, we prefer a justidentified model to an overidentified one in which the number of instruments exceeds the 
number of endogenous variables. The intent in estimating an overidentified model is to examine the exogeneity of instruments. Increasing the number of instruments does not significantly improve the prediction accuracy of remittances and migration but is more likely to be subject to invalid-instruments critiques.

\section{Robustness Checks}

In addition to the identification strategy discussed above, we probe the robustness of the estimated remittance effect in several other ways but find little evidence that undermines the main conclusion. Tables A5-A7 in the Appendix report the results of several robustness checks.

One possible concern over this causal inference is the SUTVA with respect to domestic migration. To assess how important the problem might be, we re-estimate equation [1] by controlling for the share of migrants to rural areas while working in agricultural sectors. The estimation results presented in Table A5 are qualitatively and quantitively similar to their unconditional counterparts as reported in Tables 3 and 4, indicating that the casual inference is robust to the SUTVA with respect to domestic migrants.

Another potential source of bias arises from the manner in which migration is determined. In addition to long-term migrants, we also include the number of adults who spend at least one

month away from home (i.e., household absentees) to jointly measure the extent of migration. ${ }^{5}$ If those absentees are not temporarily away from home, excluding household absentees from the analysis may compress the size of out-migration and subsequently overestimate the effect of migration on deforestation. To examine whether the negative impact of remittances on deforestation is sensitive to the exclusion of household absentees, we include absentees in the calculation of migration and re-estimate equation [1] using both the ordinary and the two-stage fractional logistic regressions. Results indicate that the negative effect of remittances on 
deforestation persists (Table A6), with slightly larger magnitudes than those reported in Tables 3 and 4. There is again no significant correlation between migration and exchange rate shocks, regardless of what factors are used to weight exchange rate change of each currency.

Another round of robustness check involves the elimination of wards where there were no migrants. Of the 3,889 households, 1,202 received remittances, leading to a reduced sample of 266 wards with migrants. We re-estimate equation [1] and equations [1]-[4]-[5] on this reduced sample. Table A7 presents the primary point estimates. The sample reduction slightly lowers the magnitude of estimated remittances effect, but it does not impair the basic conclusion drawn from the full sample analyses.

\section{Exploring Household Channels of Effects}

In this subsection, we explore the possible channels underlying the mitigating effect of remittances on deforestation from the perspectives of households' productive and consumptive activities. Specifically, using household level data from NLSS 2003/04, we examine whether remittances may have reduced pressure on forestland by changing agricultural outputs and input use (fertilizers and pesticides, improved seeds, irrigation, and hired labor). We also examine whether remittances may have reduced timber and fuelwood demands through changing materials for building house and cooking. These response variables are regressed separately on remittances. Two-stage Tobit regression is applied to the estimation of models in which response variables are bounded below by a significant number of zero-valued observations and two-stage probit regression is applied to the estimation of models with binary response variables, by instrumenting remittances and migration with the household-level exchange rate shocks and proportion of migrants to developed countries (the estimation results without IVs are reported in Table A9 of the Appendix). We assume independence across wards, allowing the households 
within each ward to be correlated. With a large number of clusters and relatively small cluster sizes, the estimates are robust to arbitrary within cluster correlation, either in linear or nonlinear models (Wooldridge 2002).

Table 5 presents the primary point estimates on the productive side. Columns 1 and 2 presents the results from the first-stage regression. ${ }^{6}$ Columns 3 and 4 correspond to the secondstage linear regression on the natural logarithm of per hectare output (i.e., yield) and total output of agricultural products, respectively. The logarithmic scale helps to correct the skewed distributions of the response variables. Columns 5-7 correspond to second-stage Tobit regression on fertilizers/pesticides expense, irrigation charge, and hired labor expense, respectively. Column 8 present estimates from second-stage Poisson regression on the proportion of improved seeds adopted by a household (the estimates are robust to more general specifications such as negative binomial regression that is capable of addressing over-dispersion).

Results indicate that agricultural outputs, either on a per-hectare basis or in total, are not affected by remittance income. In the context of Nepal, the limited supply and access to fertilizers/pesticides and the limited adoption of improved seeds underlie the story. Most farms in Nepal are subsistence farms. They do not have access to year-round irrigation facilities. The use of quality fertilizer and improved seeds is minimal due to its supply constraints. It is widely recognized that most developing countries are confronted with multiple constraints to agricultural production due to poor road infrastructure and communication networks that often prohibit timely distribution of external inputs, thereby reducing the chance of using fertilizers/pesticides or adopting new farm technologies. These constraints are evidenced by the statistical insignificance of remittance effect estimates in the fertilizer/pesticide equation, irrigation expenditure equation, and improved seeds adoption equation. 
The effect of remittances on labor hiring expense is different from the foregoing factors. It proves to be significantly positive at the $5 \%$ level even when the effect of migration is controlled for. While out-migration is likely to encourage rural households to hire more labor to cope with family labor shortage, extra income made the substitution more affordable. Similar findings were discovered by Oldekop et al. (2018). Using data from Nepal's national census and a matchingbased regression analysis, Oldekop et al. (2018) found that VDCs with high levels of international outmigration in 2001 experienced substantial increases in local forest cover during 2000-2012 and the effect of outmigration is in part mediated by reductions in the number of months that households dedicate to agriculture, manifesting a migration-induced labor shortage in farming activities.

In general, studies are divided between those arguing that migration undermines agricultural systems and those arguing that labor scarcity can be overcome and remittances are dedicated to land purchases and agricultural improvements (Jokisch 2002). Reviewing earlier evidence, Jokisch (2002) concludes that the dominant thought had been that remittances are more dedicated to family needs and consumption than to investment in agricultural systems (Jokisch 2002). A more recent review of case study evidence by Radel et al (2019) similarly suggests that migration had relatively weak effects on agricultural activities in Latin America. Nevertheless, the relationship between migration, labor shortages and agricultural production is highly context dependent (Davis, Carletto, and Winters 2010). Migrant investment in agriculture, for example, will only take place where market incentives are high, social and physical infrastructure is available, and environmental conditions are favorable; remittances alone cannot overcome most structural obstacles (Radel et al. 2019). 
On the household consumption side, results suggest that in Nepal, forest products tend to be inferior goods for which there is decreased demand when income rises. As shown in Table 6, remittance income reduced the number of new rooms made of wood materials (col. 3), a proxy for timber demand, but increased the number of new rooms made of non-wood materials (col. 4). This result implies that higher remittance income stimulated demand for non-wood materials such as metal and cement to substitute for timber in housing construction, resulting in a declined demand for timber. Jokisch (2002) notes that construction of housing is seen as symbols of success by migrants, and that many migrant sending zones have seen housing related conspicuous consumption. Likewise, the propensity for using firewood for cooking decreased with remittance income (col. 5) and the propensity for using fossil fuels increased with remittance income (col. 6), implying that households receiving more money through remittances were more likely to switch from firewood to fossil fuels such as kerosene and liquefied petroleum gas for cooking. This result consists with Baland et al. (2010), who found a negative impact of income growth on firewood collection in Nepal. Oldekop et al. (2018) also found that VDCs with high levels of international outmigration in Nepal experienced a substantial reduction in poverty in Nepal, where the poverty index is partially measured by households' fuelwood consumption. Our result supports the theory that migration, in particular, losing labor and gaining remittances, changes the cost-minimizing combination of fuels used to meet household energy needs in developing countries, which depends on energy prices and the value of time (Manning and Taylor 2014).

In summary, results from exploring household channels suggest that income increase through remittances did not increase demand for agricultural land or forests products. Rather, this income 
growth motivated farmers to substitute non-wood materials for wood materials in home construction and cooking. Consequently, the pressure on forest resources was relieved.

\section{Discussion}

The analysis above indicates that remittance income reduced deforestation in the decade 20012010. How large is this effect? Our calculation reveals that during this period, remittances reduced deforestation by 4.2 percentage points, accounting for almost $12 \%$ of deforestation that has occurred in the decade. We base this value on a comparison of the estimated expected deforestation rate between the factual experiment (35.2\%) and a counterfactual experiment (39.4\%) without the remittances received from households, using the estimated marginal effect of remittances on deforestation (-0.435 as reported in col. 3c of Table 4$)$.

Migration is an enormous phenomenon that has been taking place at various scales throughout the world. Remittances sent by migrants are remarkable capital flows for families of migrants' origins, especially in developing countries (Viet Cuong and Mont 2012). While the ultimate goal of the migration-to-development strategy would be to actually end the reliance on migration and remittances (Ellerman 2003), it is likely that migration will remain an important income source and livelihood activity for Nepal in the foreseeable future. Policies should make migration and remittances not only "work for development" for instance by encouraging productive investment of remittances (McKenzie and Sasin 2007), but also "work for the environment" and "work for sustainability." Taking fuelwood use as an example, remittances help to reduce households' fuelwood consumption, but the benefits go beyond forest protection. There are indirect impacts on the households, such as spending less time collecting fuelwood (especially by women and youths) and improved indoor air quality by switching to modern fuels; both are relevant outcomes targeted by the United Nations Sustainable Development Goals. In 
developing nations, 2.4 billion people — more than a third of the world population — rely on wood or other biomass fuels for cooking and heating (WRI 2005). Given the extent of fuelwood consumption and depending on the degree to which the effect of remittances as found for Nepal holds for other developing countries, the benefits are potentially enormous.

Findings from the channel analysis are generally consistent with Oldekop et al. (2018). However, our study differs from Oldekop et al. (2018) in at least two aspects. First, our study focuses on remittances-forest cover change relationship whereas Oldekop et al. (2018) focuses on migration-forest cover change relationship. Oldekop et al. (2018) discusses three key mechanisms for migration to affect reforestation, including two that are related to remittances and one related to agricultural labor. Our study controls for the effect of agricultural labor and focuses on remittances-mediated impact on deforestation. In a sense, our study extends Oldekop et al. (2018) with an in-depth follow-up analysis of the remittances-related channels of impact of migration.

Moreover, our study focuses on detecting deforestation, rather than reforestation (or afforestation) as Oldekop et al. (2018) does. According to Rudel et al. (2005), deforestation takes place when people clear land of trees and regrowth does not occur; afforestation occurs when forest cover expands through the planting of trees on lands without trees; whereas reforestation occurs when forests spontaneously regenerate on previously forested lands. The decision-making around deforestation may vary from that of afforestation or forest regeneration, resulting in different drivers of the two types of forest cover change, though related. Combining insights from both studies offers a more complete picture of what happened in forest cover in Nepal. That is, there is indication that migration flows and remittances have jointly resulted in both reduction in forest clearing and increase in reforestation during the first decade of the $21^{\text {st }}$ century. 
In this study, we demonstrate the positive role of remittances in reducing deforestation in Nepal. This win-win impact of remittances provides a potential policy opportunity to address both poverty and the conservation of valuable natural resources concurrently. This finding is in sharp contrast to El Salvador, where a remittance economy with few agricultural investment opportunities within reach of migrant families is found to cause a contraction of farming activities and associated forest expansion (Hecht et al. 2006; Hecht and Saatchi 2007). Future research is needed to test whether the finding is context-dependent and to what degree the effect of income increase through remittances holds for other developing countries. Moreover, the question of how to get involved also merits future research in order to inform polices on capitalizing on the win-win linkage. While polices encouraging migration itself might be considered controversial, policies that encourage remittances directly (McKenzie and Sasin 2007) or more productive and environmentally conscious use of remittances seem rational. Moreover, policy options that influence the channels between migration or remittances and outcomes (such as agricultural outputs, household welfare, land use, and natural resource management) also deserve attention.

\section{Conclusion}

This paper provides new evidence that income increase through remittances can ease pressure on forest resources. We find that remittance income reduced deforestation by almost $12 \%$ of the total forest loss in Nepal during the period 2001-2010. There is little evidence that remittances induced competition for land through increased modern inputs use (e.g., chemical fertilizers and pesticides, irrigation, and improved seeds) or stimulated demand for forest products. Remittance income did, however, increase expenditure on hired labor in farming activities. It also resulted in a switch of household consumption from timber and wood products to non-forest products in 
housing construction and cooking. These findings draw from a comprehensive data set including high-quality land use data and an extensive national household survey. The estimated effects are robust across a variety of specifications and estimation methods, providing strong grounds for evidence-based policy recommendations.

This study contributes to the debate about potential tension or synergy between development and conservation. The widespread transfer of monies from foreign workers to their home countries - the sending of remittances — is among the largest of global capital flows, and occurs throughout Africa, the Middle East, Asia as well as Latin America (Hecht 2010). These remittances directly augment the income of those receiving households, significantly reducing poverty across the world. Rural development and conservation debates must consider the environmental ramifications of migration and remittance economies, taking into account the dynamic interactions among micro and macro processes that shape policies and individual actions. 


\section{Acknowledgments}

The work was carried out under the CGIAR Research Program on Water, Land, and Ecosystems (WLE) with support from CGIAR Fund Donors (http://www.cgiar.org/about-us/our-funders/). Li is supported by Hatch Capacity Grant Project no. UTA-01510 from the USDA National Institute of Food and Agriculture. The authors owe great thanks to Dr. Valerie Mueller for valuable comments and to Mr. Bijaya R. Gautam of the Informal Sector Service Center (INSEC) in Nepal for the informative discussion about the conflict death data. The authors are also grateful to Basudev Timilsina for providing data on the forest user group registers for the community forestry program and Prachanda Pradhan for many informative discussions about the study context. 


\section{References}

Aide, T. Mitchell, and H. Ricardo Grau. 2004. "Globalization, Migration, and Latin American Ecosystems." Science 305 (5692): 1915-6. https://doi.org/10.1126/science.1103179.

Aide, T. Mitchell, Matthew L. Clark, H. Ricardo Grau, David López-Carr, Marc A. Levy, Daniel Redo, Martha Bonilla-Moheno, George Riner, María J. Andrade-Núñez, and María Muñiz. 2013. "Deforestation and Reforestation of Latin America and the Caribbean (2001-2010)." Biotropica 45 (2): 262-71. https://doi.org/10.1111/j.1744-7429.2012.00908.x.

Alix-Garcia, Jennifer, Craig McIntosh, Katharine R. E. Sims, and Jarrod R. Welch. 2013. “The Ecological Footprint of Poverty Alleviation: Evidence from Mexico's Oportunidades Program." The Review of Economics and Statistics 95 (2): 417-35. https://doi.org/10.1162/REST_a_00349.

Angelsen, Arild. 2010. "Policies for Reduced Deforestation and Their Impact on Agricultural Production." Proceedings of the National Academy of Sciences of the United States of America 107 (46): 19639-44. https://doi.org/10.1073/pnas.0912014107.

Angelsen, Arild, and David Kaimowitz. 1999. "Rethinking the Causes of Deforestation: Lessons from Economic Models.” World Bank Research Observer 14 (1): 73-98. https://doi.org/10.1093/wbro/14.1.73.

Angrist, Joshua D., Guido W. Imbens, and Donald B. Rubin. 1996. "Identification of Causal Effects Using Instrumental Variables.” Journal of the American Statistical Association 91 (434): 444-55. https://doi.org/10.2307/2291629.

Baland, Jean-Marie, Pranab Bardhan, Sanghamitra Das, Dilip Mookherjee, and Rinki Sarkar. 2010. "The Environmental Impact of Poverty: Evidence from Firewood Collection in Rural 
Nepal." Economic Development and Cultural Change 59 (1): 23-61.

https://doi.org/10.1086/655455.

Barbier, Edward B., and Joanne C. Burgess. 1996. "Economic Analysis of Deforestation in Mexico." Environment and Development Economics 1 (2): 203-39. https://doi.org/10.1017/S1355770X00000590.

Bennett, Lynn, Dilli Ram Dahal, and Pav Govindasamy. 2008. Caste, Ethnic and Regional Identity in Nepal: Further Analysis of the 2006 Nepal Demographic and Health Survey. DHS Further Analysis Reports No. 58. Calverton, MD, USA: Macro International.

Capistrano, Ana Doris, and Clyde F. Kiker. 1995. "Macro-scale Economic Influences on Tropical Forest Depletion.” Ecological Economics 14 (1): 21-9. https://doi.org/10.1016/0921-8009(95)00008-W.

Chinn, Menzie, 2003. Explaining Exchange Rate Behavior. NBER Reporter: No. 2, June 2003. Cambridge, MA: National Bureau of Economic Research. Available at https://www.nber.org/reporter/spring03/explaininge.html.

Cox, Donald, Zekeriya Eser, and Emmanuel Jimenez. 1998. "Motives for Private Transfers over the Life Cycle: An Analytical Framework and Evidence for Peru." Journal Development Economics 55 (1): 57-80. https://doi.org/10.1016/S0304-3878(97)00056-4.

Dahal, Ganga Ram, and Apsara Chapagain. 2008. “Community Forestry in Nepal: Decentralized Forest Governance.” In Lessons from Forest Decentralization: Money, Justice and the Quest for Good Governance in Asia-Pacific, ed. C.J.P. Colfer, G.R. Dahal, and D. Capistrano, 67-81. London, United Kingdom: Earthscan. 
Davis, Benjamin, Gero Carletto, and Paul C. Winters. 2010. "Migration, Transfers and Economic Decision Making among Agricultural Households: An Introduction.” Journal of Development Studies 46 (1): 1-13. https://doi.org/10.1080/00220380903198000.

de la Brière, Bénédicte, Elisabeth Sadoulet, Alain de Janvry, and Sylvie Lambert. 2002. “The Roles of Destination, Gender, and Household Composition in Explaining Remittances: An Analysis for the Dominican Sierra.” Journal Development Economics 68 (2): 309-28. https://doi.org/10.1016/S0304-3878(02)00015-9.

DFRS (Department of Forest Research and Survey). 1999. Forest Resources of Nepal (19871998). Publication No. 74. Kathmandu, Nepal: DFRS, Ministry of Forests and Soil Conservation, HMG Nepal, and Forest Resource Information System Project, Government of Finland.

Ellerman, David. 2003. "Policy Research on Migration and Development.” Policy Research Working Paper no. WPS 3117. Washington DC: World Bank.

FAO (Food and Agriculture Organization). 2006. Global Forest Resources Assessment 2005: Progress towards Sustainable Forest Management. Forestry Paper 147. Rome, Italy: Food and Agriculture Organization of the United Nations.

Gray, Clark L. 2009. "Environment, Land, and Rural Out-migration in the Southern Ecuadorian Andes." World Development 37 (2): 457-68. https://doi.org/10.1016/j.worlddev.2008.05.004.

Gray, Clark L., and Richard E. Bilsborrow. 2014. "Consequences of Out-migration for Land Use in Rural Ecuador.” Land Use Policy 36: 182-91. https://doi.org/10.1016/j.landusepol.2013.07.006.

Guo, Zhe, Ranjay Shrestha, Wei Zhang, Prapi Bhandary, Gennong Yu, and Liping Di. 2015. "Land cover classification and change detection analysis using LandSat series and geospatial 
datasets in Nepal from 1980 to 2010.” 2015 Fourth International Conference on Agrogeoinformatics, IEEE conference proceedings, pp. 414-18, July 20-24. https://doi.org/10.1109/Agro-Geoinformatics.2015.7248159.

Hecht, Susanna B., Susan Kandel, Ileana Gomes, Nelson Cuellar, and Herman Rosa. 2006. "Globalization, Forest Resurgence, and Environmental Politics in El Salvador." World Development 34 (2): 308-23. https://doi.org/10.1016/j.worlddev.2005.09.005.

Hecht, Susanna B., and Sassan S. Saatchi. 2007. Globalization and Forest Resurgence: Changes in Forest Cover in El Salvador. BioScience 57 (8): 663-72. https://doi.org/10.1641/B570806.

Hecht, Susanna. 2010. “The New Rurality: Globalization, Peasants and the Paradoxes of Landscapes." Land Use Policy 27 (2): 161-69. https://doi.org/10.1016/j.landusepol.2009.08.010.

Ilahi, Nadeem, and Saqib Jafarey. 1999. "Guest-worker Migration, Remittances and the Extended Family: Evidence from Pakistan.” Journal Development Economics 58(2): 485-512. https://doi.org/10.1016/s0304-3878(98)00122-9.

Jokisch, Brad D. 2002. "Migration and Agricultural Change: The Case of Smallholder Agriculture in Highland Ecuador." Human Ecology 30: 523-50. https://doi.org/10.1023/A:1021198023769.

Kanel, Keshav Raj. 2012. Current Status of Community Forestry in Nepal. Report submitted to Regional Community Forestry Training Center for Asia and the Pacific, Bangkok, Thailand. Available at https://www.recoftc.org/sites/default/files/publications/resources/recoftc0000176-0001-en.pdf.

Katz, Eliakim, and Oded Stark. 1986. "Labor Migration and Risk Aversion in Less Developed Countries." Journal of Labor Economics 4 (1): 134-49. https://doi.org/10.1086/298097. 
Kull, Christian A., Camellia K. Ibrahim, and Thomas C. Meredith. 2007. "Tropical Forest Transitions and Globalization: Neo-Liberalism, Migration, Tourism, and International Conservation Agendas." Society and Natural Resources 20 (8): 723-37. https://doi.org/10.1080/08941920701329702.

Li, Man, Alessandro De Pinto, John M. Ulimwengu, Liangzhi You, and Richard D. Robertson. 2015. "Impacts of Road Expansion on Deforestation and Biological Carbon Loss in the Democratic Republic of Congo.” Environmental and Resource Economics 60 (3): 433-69. https://doi.org/10.1007/s10640-014-9775-y.

López-Feldman, Alejandro, and Estefanía Chávez. 2017. "Remittances and Natural Resource Extraction: Evidence from Mexico.” Ecological Economics 132: 69-79. https://doi.org/10.1016/j.ecolecon.2016.10.010.

Manning, Dale T., and J. Edward Taylor. 2014. "Migration and Fuel Use in Rural Mexico." Ecological Economics 102: 126-36. https://doi.org/10.1016/j.ecolecon.2014.03.012.

Massey, Douglas S. Joaquin Arango, Graeme Hugo, Ali Kouaouci, Adela Pellegrino, and J. Edward Taylor. 1993. "Theories of international migration: A review and appraisal." Population and Development Review 19 (3): 431-66. https://doi.org/10.2307/2938462.

Massey, Douglas S., William G. Axinn, and Dirgha J. Ghimire. 2010. "Environmental Change and Out-Migration: Evidence from Nepal." Population and Environment, 32 (2): 109-36. https://doi.org/10.1007/s11111-010-0119-8.

McKenzie, David, and Marcin J. Sasin. 2007. "Migration, Remittances, Poverty, and Human Capital: Conceptual and Empirical Challenges.” Policy Research working paper no. WPS 4272. Washington, DC: World Bank. https://doi.org/10.1596/1813-9450-4272. 
Meese, Richard A., and Kenneth Rogoff. 1983. "Empirical Exchange Rate Models of the Seventies: Do They Fit Out of Sample?” Journal of International Economics 14 (1-2): 3-24. https://doi.org/10.1016/0022-1996(83)90017-X.

Montgomery, James D. 1991. "Social Networks and Labor-Market Outcomes: Toward an Economic Analysis.” American Economic Review 81(5): 1408-18.

Moosa, Imad, and Kelly Burns. 2014. “The Unbeatable Random Walk in Exchange Rate Forecasting: Reality or Myths?” Journal of Macroeconomics 40: 69-81. https://doi.org/10.1016/j.jmacro.2014.03.003.

Munshi, Kaivan. 2003. "Networks in the Modern Economy: Mexican Migrants in the U.S. Labor Market.” Quarterly Journal of Economics 118 (2): 549-99. https://doi.org/10.1162/003355303321675455.

NCBS (Nepal Central Bureau of Statistics). 2003. Population Monograph of Nepal 2003 (Volume 1). Kathmandu, Nepal: National Planning Commission Secretariat, Nepal Central Bureau of Statistics. Available at https://mohp.gov.np/downloads/Population\%20Monograph\%20V01.pdf.

Neupane, Hari. 2003. “Contested Impact of Community Forestry on Equity: Some Evidences from Nepal." Journal of Forest and Livelihood 2 (2): 55-62. Available at https://www.forestaction.org/app/webroot/vendor/tinymce/editor/plugins/filemanager/files/i mages/stories/pdfs/journal_of_forest_and_livelihood/vol2_2/Hari\%20Neupane8.pdf.

Oldekop, Johan A., Katharine R.E. Sims, Mark J. Whittingham, and Arun Agrawal. 2018. “An Upside to Globalization: International Outmigration Drives Reforestation in Nepal." Global Environmental Change 52: 66-74. https://doi.org/10.1016/j.gloenvcha.2018.06.004. 
OPHI (Oxford Poverty and Human Development Initiative). 2020. Nepal Country Briefing. Multidimensional Poverty Index Data Bank. Oxford Poverty and Human Development Initiative, University of Oxford. Available at http://www.ophi.org.uk/multidimensionalpoverty-index/mpi-country-briefings/.

Papke, Leslie E., and Jeffrey M. Wooldridge. 1996. "Econometric Methods for Fractional Response Variables with an Application to 401(k) Plan Participation Rates." Journal of Applied Econometrics 11 (6): 619-32. https://doi.org/10.1002/(SICI)10991255(199611)11:6<619::AID-JAE418>3.0.CO;2-1.

Perfecto, Ivette, and John Vandermeer. 2010. "The Agroecological Matrix as Alternative to the Land-Sparing/Agriculture Intensification Model." Proceedings of the National Academy of Sciences of the United States of America 107 (13): 5786-91. https://doi.org/10.1073/pnas.0905455107.

Radel, Claudia, Brad D. Jokisch, Birgit Schmook, Lindsey Carte, Mariel Aguilar-Støen, Kathleen Hermans, Karl Zimmerer, and Stephen Aldrich. 2019. "Migration as a Feature of Land System Transitions.” Current Opinion in Environmental Sustainability 38: 103-10. https://doi.org/10.1016/j.cosust.2019.05.007.

Rudel, Thomas K. 1998. "Is There a Forest Transition? Deforestation, Reforestation, and Development." Rural sociology 63 (4): 533-52. https://doi.org/10.1111/j.15490831.1998.tb00691.x.

Rudel, Thomas K., Oliver T. Coomes, Emilio Moran, Frederic Achard, Arild Angelsen, Jianchu Xu, and Eric Lambin. 2005. "Forest Transitions: Towards a Global Understanding of Land Use Change." Global Environmental Change 15 (1): 23-31. https://doi.org/10.1016/j.gloenvcha.2004.11.001. 
Staiger, Douglas, and James H. Stock. 1997. "Instrumental Variables Regression with Weak Instruments.” Econometrica 65 (3): 557-86. https://doi.org/10.2307/2171753.

Tiwari, Sailesh, and Keshav Bhattarai. 2011. "Migration, Remittances and Forests:

Disentangling the Impact of Population and Economic Growth on Forests.” Policy Research working paper no. WPS 5907. Washington, DC: World Bank. https://doi.org/10.1596/18139450-5907.

Viet Cuong, Nguyen, and Daniel Mont. 2012. "Economic Impacts of International Migration and Remittances on Household Welfare in Vietnam." International Journal of Development Issues, 11 (2): 144-63. https://doi.org/10.1108/14468951211241137.

Wooldridge, Jeffrey M. 2002. Econometric Analysis of Cross Section and Panel Data. Cambridge, MA: MIT Press

WRI (World Resources Institute). 2005. World Resources 2005: The Wealth of the PoorManaging Ecosystems to Fight Poverty. Washington, DC: World Resources Institute.

Yang, Dean. 2008. “International Migration, Remittances and Household Investment: Evidence from Philippine Migrants’ Exchange Rate Shocks.” The Economic Journal 118 (528): 591630. https://doi.org/10.1111/j.1468-0297.2008.02134.x

Zwane, Alix Peterson. 2007. "Does Poverty Constrain Deforestation? Econometric Evidence from Peru." Journal of Development Economics 84 (1): 330-49. https://doi.org/10.1016/j.jdeveco.2005.11.007. 


\section{Tables}

Table 1. Summary Statistics of Sample Ward Characteristics

\begin{tabular}{|c|c|c|c|c|}
\hline \multirow[b]{2}{*}{ Variable } & \multicolumn{2}{|c|}{ Full sample } & \multicolumn{2}{|c|}{$\begin{array}{c}\text { Sample with } \\
\text { wards receiving } \\
\text { remittances }\end{array}$} \\
\hline & Mean & $\begin{array}{r}\text { Standard } \\
\text { deviation }\end{array}$ & Mean & $\begin{array}{r}\text { Standard } \\
\text { deviation }\end{array}$ \\
\hline Ward area (ha) & 452.0 & 1169.5 & 461.6 & 1193.5 \\
\hline$\%$ ward in agriculture in 2001 & 51.4 & 30.0 & 51.6 & 29.6 \\
\hline$\%$ ward in forests in 2001 & 45.1 & 30.3 & 45.4 & 30.0 \\
\hline$\%$ deforestation during 2001-2010 & 36.4 & 30.5 & 35.9 & 30.3 \\
\hline Average remittances received by household (100,000 Rs) & 0.094 & 0.111 & 0.098 & 0.112 \\
\hline Average number of family migrants & 0.414 & 0.265 & 0.432 & 0.256 \\
\hline Average number of family absentees & 0.095 & 0.074 & 0.096 & 0.073 \\
\hline Median annual precipitation $(1,000 \mathrm{~mm})$ & 1.898 & 0.724 & 1.908 & 0.725 \\
\hline Interquartile range of annual precipitation $(1,000 \mathrm{~mm})$ & 0.261 & 0.100 & 0.260 & 0.096 \\
\hline District average conflict-related death toll during 2002-2004 & 144 & 95 & 145 & 95 \\
\hline Share of high-caste households (including Newar) & 0.412 & 0.332 & 0.417 & 0.329 \\
\hline Share of Dalits and low-caste households & 0.130 & 0.161 & 0.132 & 0.162 \\
\hline Share of Janajati households & 0.344 & 0.315 & 0.339 & 0.312 \\
\hline Average age of household heads (years) & 46.0 & 4.90 & 46.1 & 4.93 \\
\hline Share of male headship & 0.794 & 0.151 & 0.788 & 0.151 \\
\hline Average formal education of household heads (years) & 2.45 & 1.63 & 2.45 & 1.62 \\
\hline Per capita land endowment (ha) & 0.201 & 0.114 & 0.199 & 0.111 \\
\hline Is the ward involved community forestry program ( 1 if yes)? & 0.287 & 0.453 & 0.299 & 0.459 \\
\hline Exchange rate shocks of overseas remittances in a ward (\%) & 2.22 & 2.40 & 2.31 & 2.41 \\
\hline Exchange rate shocks of overseas remittances in a district (\%) & 0.889 & 0.703 & 0.902 & 0.707 \\
\hline Share of migrants to developed countries & 0.089 & 0.167 & 0.093 & 0.170 \\
\hline Observations & 281 & & 266 & \\
\hline
\end{tabular}

Note: Stratum weights are applied to the calculation. 
Table 2. Location of Migrants from Sample Households

\begin{tabular}{lrrr}
\hline Location & $\begin{array}{r}\text { Number of } \\
\text { Migrants }\end{array}$ & $\begin{array}{r}\text { \% of } \\
\text { total }\end{array}$ & $\begin{array}{r}\text { Exchange rate shock, } \\
\text { 2000-2003 (\%) }\end{array}$ \\
\hline Nepal & 760 & 50.8 & - \\
India & 480 & 32.1 & 2.9 \\
Saudi Arabia & 82 & 5.5 & 14.5 \\
Malaysia & 52 & 3.5 & 10.8 \\
Qatar & 37 & 2.5 & 47.6 \\
United Arab Emirates & 14 & 0.9 & 14.1 \\
United States & 12 & 0.8 & 5.0 \\
United Kingdom & 12 & 0.8 & 5.0 \\
Hong Kong, China & 10 & 0.7 & -16.8 \\
Japan & 6 & 0.4 & -9.9 \\
Other countries & 32 & 2.1 & n.a. \\
Total & 1,497 & 100.0 & \\
\hline
\end{tabular}

Source: Authors' calculations using data are from NLSS 2003/04 and the IMF rates database. Exchange rate shock is percent change in Nepalese rupees per currency unit over the period 2000-2003. 
Table 3. Estimation on Deforestation without Instrumental Variables

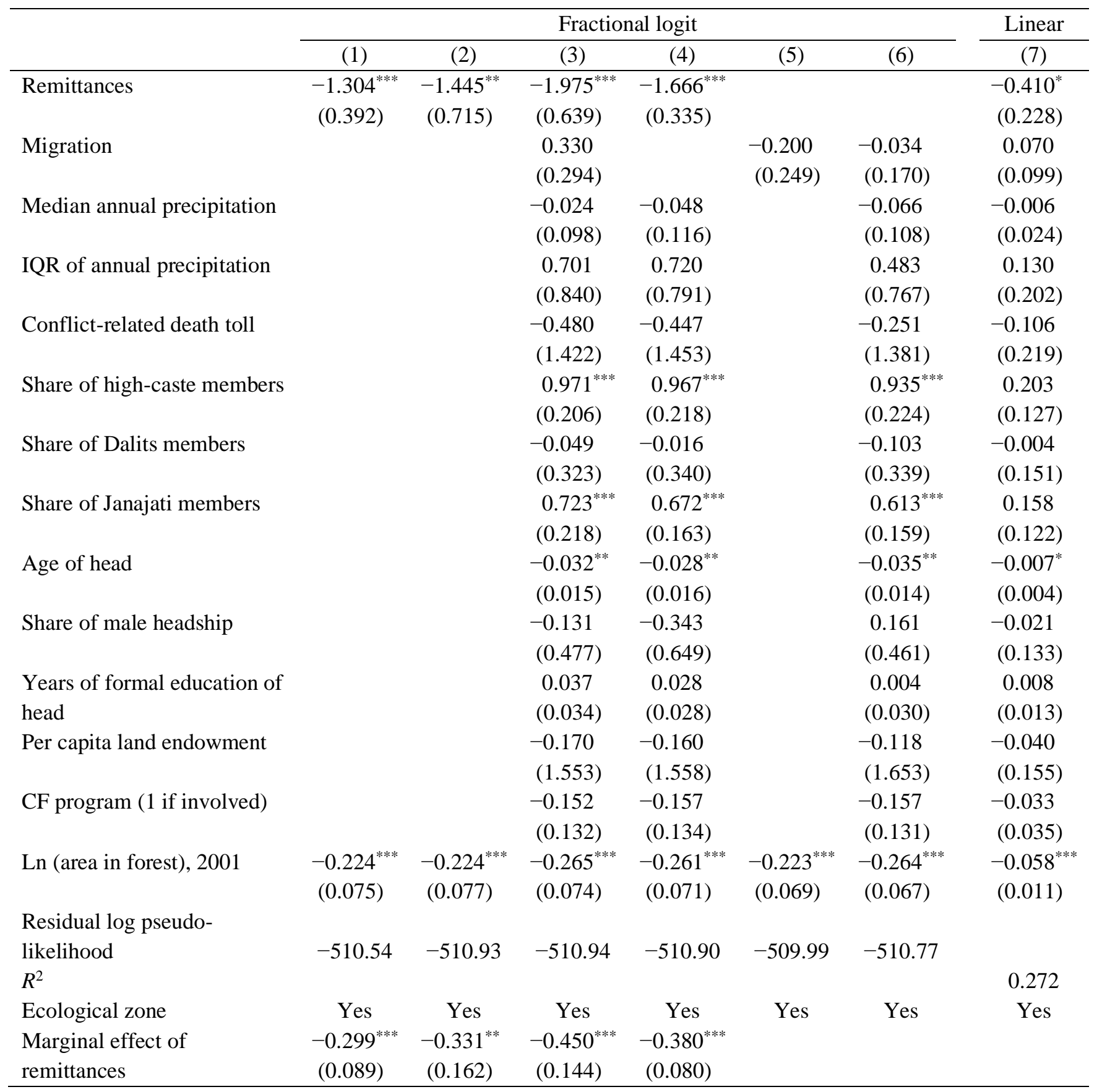

Note: The sample includes 281 wards. Normalized stratum weights are applied to the estimation of all the models. Standard error is in parentheses. *, **, and *** indicate statistical significance at the 10,5 , and $1 \%$ levels, respectively. Marginal effect is evaluated at the sample means with the standard error being calculated using the delta method. 
Table 4. Estimated Remittances Effect on Deforestation Using Instrumental Variable Approach

\begin{tabular}{|c|c|c|c|c|c|c|c|c|c|c|}
\hline & \multicolumn{4}{|c|}{ Parsimonious two-stage fractional logit } & \multicolumn{6}{|c|}{ Comprehensive two-stage fractional logit } \\
\hline & $\begin{array}{c}\text { Remittances } \\
\text { (1a) }\end{array}$ & $\begin{array}{c}\text { Deforestation } \\
\text { (1b) }\end{array}$ & $\begin{array}{c}\text { Remittances } \\
(2 \mathrm{a})\end{array}$ & $\begin{array}{c}\text { Deforestation } \\
(2 \mathrm{~b})\end{array}$ & $\begin{array}{c}\text { Remittances } \\
(3 \mathrm{a}) \\
\end{array}$ & $\begin{array}{l}\text { Migration } \\
(3 b)\end{array}$ & $\begin{array}{c}\text { Deforestation } \\
(3 \mathrm{c}) \\
\end{array}$ & $\begin{array}{c}\text { Remittances } \\
(4 a)\end{array}$ & $\begin{array}{l}\text { Migration } \\
(4 \mathrm{~b})\end{array}$ & $\begin{array}{c}\text { Deforestation } \\
(4 \mathrm{c})\end{array}$ \\
\hline \multicolumn{11}{|c|}{ Panel A. Parameter estimates } \\
\hline Remittances & & $\begin{array}{r}-1.003^{*} \\
(0.603)\end{array}$ & & $\begin{array}{c}-0.980^{*} \\
(0.582)\end{array}$ & & & $\begin{array}{l}-1.906^{* *} \\
(0.819)\end{array}$ & & & $\begin{array}{l}-1.927^{* *} \\
(0.811)\end{array}$ \\
\hline Migration & & & & & & & $\begin{array}{c}0.076 \\
(0.726)\end{array}$ & & & $\begin{array}{c}0.064 \\
(0.724)\end{array}$ \\
\hline $\begin{array}{l}\text { Exchange rate shocks } \\
\text { (ward level) }\end{array}$ & $\begin{array}{l}0.025^{* * *} \\
(0.002)\end{array}$ & & $\begin{array}{l}0.024^{* * *} \\
(0.002)\end{array}$ & & $\begin{array}{l}0.012^{* * *} \\
(0.003)\end{array}$ & $\begin{array}{c}-0.003 \\
(0.008)\end{array}$ & & $\begin{array}{l}0.011^{* * *} \\
(0.003)\end{array}$ & $\begin{array}{c}-0.004 \\
(0.009)\end{array}$ & \\
\hline $\begin{array}{l}\text { Exchange rate shocks } \\
\text { (district level) }\end{array}$ & & & $\begin{array}{l}0.020^{* *} \\
(0.008)\end{array}$ & & & & & $\begin{array}{l}0.017^{* *} \\
(0.008)\end{array}$ & $\begin{array}{c}0.015 \\
(0.020)\end{array}$ & \\
\hline Developed countries & & & & & $\begin{array}{l}0.171^{* * *} \\
(0.047)\end{array}$ & $\begin{array}{c}0.232^{*} \\
(0.123)\end{array}$ & & $\begin{array}{l}0.193^{* * *} \\
(0.048)\end{array}$ & $\begin{array}{l}0.250^{* *} \\
(0.126)\end{array}$ & \\
\hline Control variables $\mathbf{W}$ & No & No & No & No & Yes & Yes & Yes & Yes & Yes & Yes \\
\hline $\begin{array}{l}\text { Control variables } \mathbf{X} \\
\text { Marginal effect of } \\
\text { remittances }\end{array}$ & Yes & $\begin{array}{c}\text { Yes } \\
-0.230^{*} \\
(0.138)\end{array}$ & Yes & $\begin{array}{c}\text { Yes } \\
-0.225^{*} \\
(0.134)\end{array}$ & Yes & Yes & $\begin{array}{c}\text { Yes } \\
-0.435^{* *} \\
(0.187)\end{array}$ & Yes & Yes & $\begin{array}{c}\text { Yes } \\
-0.440^{* *} \\
(0.186)\end{array}$ \\
\hline \multicolumn{11}{|c|}{ Panel B. Test and fit statistics } \\
\hline $\begin{array}{l}\text { Instrument } F \text {-test } \\
(p \text {-value })\end{array}$ & $\begin{array}{l}110.6^{* * *} \\
(<.0001)\end{array}$ & & $\begin{array}{l}59.3^{* * *} \\
(<.0001)\end{array}$ & & $\begin{array}{l}55.6^{* * *} \\
(<.0001)\end{array}$ & $\begin{array}{c}3.04^{* *} \\
(0.050)\end{array}$ & & $\begin{array}{l}39.3^{* * *} \\
(<.0001)\end{array}$ & $\begin{array}{c}2.19^{*} \\
(0.089)\end{array}$ & \\
\hline $\begin{array}{l}\text { Wu-Hausman test } \\
\text { ( } p \text {-value) }\end{array}$ & & $\begin{array}{c}0.030 \\
(0.859)\end{array}$ & & $\begin{array}{c}0.040 \\
(0.840)\end{array}$ & & & $\begin{array}{c}0.337 \\
(0.947)\end{array}$ & & & $\begin{array}{c}0.498 \\
(0.864)\end{array}$ \\
\hline $\begin{array}{l}\text { Overidentification } \\
\text { test ( } p \text {-value) }\end{array}$ & & & & $\begin{array}{c}0.110 \\
(0.740)\end{array}$ & & & & & & $\begin{array}{c}1.550 \\
(0.213)\end{array}$ \\
\hline$R^{2}$ & 0.293 & & 0.308 & & 0.510 & 0.408 & & 0.519 & 0.401 & \\
\hline
\end{tabular}

Note: The sample includes 281 wards. Normalized household weights are applied to the estimation of all the models. Standard error is in parentheses except the three test statistics reported in Panel B where associated $p$-value is in parentheses. ** and *** indicate statistical significance at the 5 and $1 \%$ levels, respectively. Marginal effect estimates are evaluated at the sample of remittances. Marginal effect is evaluated at the sample means with the standard error being calculated using the delta method. 
Table 5. Estimated Remittances Effects on Household Farming Activities

\begin{tabular}{|c|c|c|c|c|c|c|c|c|}
\hline & \multicolumn{2}{|c|}{ First stage } & \multicolumn{6}{|c|}{ Second stage } \\
\hline & \multirow[b]{2}{*}{$\begin{array}{c}\text { Remittances } \\
\text { (1) }\end{array}$} & \multirow[b]{2}{*}{$\begin{array}{l}\text { Migration } \\
\text { (2) }\end{array}$} & \multicolumn{2}{|c|}{ Linear } & \multicolumn{3}{|c|}{ Tobit } & \multirow{2}{*}{$\begin{array}{c}\text { Poisson } \\
\text { Adoption of } \\
\text { improved seeds } \\
(8)\end{array}$} \\
\hline & & & $\begin{array}{c}\operatorname{Ln}(\text { yield) } \\
\text { (3) }\end{array}$ & $\begin{array}{l}\text { Ln (total } \\
\text { Outputs) } \\
(4)\end{array}$ & $\begin{array}{c}\text { Fertilizer \& } \\
\text { pesticides } \\
(5)\end{array}$ & $\begin{array}{c}\text { Irrigation/water } \\
\text { course maintenance } \\
(6)\end{array}$ & $\begin{array}{l}\text { Expenditure on } \\
\text { labor hiring } \\
(7)\end{array}$ & \\
\hline \multicolumn{9}{|c|}{ Panel A. Parameter estimates } \\
\hline Remittances & & & $\begin{array}{l}-0.221 \\
(0.236)\end{array}$ & $\begin{array}{r}0.282 \\
(0.322)\end{array}$ & $\begin{array}{c}1.382 \\
(2.183)\end{array}$ & $\begin{array}{l}-0.927 \\
(1.032)\end{array}$ & $\begin{array}{l}10.856^{* *} \\
(5.046)\end{array}$ & $\begin{array}{c}0.639 \\
(4.200)\end{array}$ \\
\hline Migration & & & $\begin{array}{c}0.094 \\
(0.194)\end{array}$ & $\begin{array}{l}-0.127 \\
(0.249)\end{array}$ & $\begin{array}{l}-1.045 \\
(1.709)\end{array}$ & $\begin{array}{c}0.696 \\
(0.782)\end{array}$ & $\begin{array}{l}-5.193 \\
(3.883)\end{array}$ & $\begin{array}{l}-0.493 \\
(3.030)\end{array}$ \\
\hline $\begin{array}{l}\text { Exchange rate shocks } \\
\text { (household level) }\end{array}$ & $\begin{array}{l}0.042^{* * *} \\
(0.011)\end{array}$ & $\begin{array}{l}0.088^{* * *} \\
(0.017)\end{array}$ & & & & & & \\
\hline Developed countries & $\begin{array}{l}0.263^{*} \\
(0.141)\end{array}$ & $\begin{array}{l}-0.268 \\
(0.236)\end{array}$ & & & & & & \\
\hline Travel time to cities & $\begin{array}{c}0.009 \\
(0.045)\end{array}$ & $\begin{array}{l}-0.137^{*} \\
(0.076)\end{array}$ & $\begin{array}{c}0.135 \\
(0.198)\end{array}$ & $\begin{array}{l}0.406^{* *} \\
(0.190)\end{array}$ & $\begin{array}{l}-3.116^{* * *} \\
(0.806)\end{array}$ & $\begin{array}{c}0.437 \\
(0.404)\end{array}$ & $\begin{array}{l}-7.820^{* * *} \\
(1.992)\end{array}$ & $\begin{array}{c}0.331 \\
(2.968)\end{array}$ \\
\hline Control variables $\mathbf{W}$ and $\mathbf{X}$ & Yes & Yes & Yes & Yes & Yes & Yes & Yes & Yes \\
\hline \multicolumn{9}{|c|}{ Panel B. Test and fit statistics } \\
\hline $\begin{array}{l}\text { Instrument } F \text {-test } \\
(p \text {-value })\end{array}$ & $\begin{array}{l}44.3^{* * *} \\
(<.0001)\end{array}$ & $\begin{array}{l}18.7^{* * *} \\
(<.0001)\end{array}$ & & & & & & \\
\hline $\begin{array}{l}\text { Wu-Hausman test } \\
(p \text {-value })\end{array}$ & & & $\begin{array}{c}0.520 \\
(0.598)\end{array}$ & $\begin{array}{c}0.660 \\
(0.515)\end{array}$ & $\begin{array}{c}1.100 \\
(0.551)\end{array}$ & $\begin{array}{c}1.410 \\
(0.494)\end{array}$ & $\begin{array}{c}6.960^{* *} \\
(0.031)\end{array}$ & $\begin{array}{c}1.230 \\
(0.542)\end{array}$ \\
\hline$R^{2}$ & 0.291 & 0.223 & & & & & & \\
\hline
\end{tabular}

Note: The sample includes 2,810 households. Normalized household weights are applied to the estimation of all the models. Standard error is in parentheses except the two test statistics reported in Panel B where associated $p$-value is in parentheses. *,**, and *** indicate statistical significance at the 10,5 , and $1 \%$ levels, respectively. 
Table 6. Estimated Remittances Effects on Household Consumption

\begin{tabular}{|c|c|c|c|c|c|c|}
\hline & \multicolumn{2}{|c|}{ First stage } & \multicolumn{4}{|c|}{ Second stage } \\
\hline & \multirow[b]{2}{*}{$\begin{array}{c}\text { Remittances } \\
\text { (1) }\end{array}$} & \multirow[b]{2}{*}{$\begin{array}{l}\text { Migration } \\
\text { (2) }\end{array}$} & \multicolumn{2}{|c|}{ Tobit } & \multicolumn{2}{|c|}{ Probit } \\
\hline & & & $\begin{array}{c}\text { Rooms made of } \\
\text { wood materials } \\
\text { (3) }\end{array}$ & $\begin{array}{c}\text { Rooms made of } \\
\text { non-wood materials } \\
(4)\end{array}$ & $\begin{array}{c}\text { Firewood } \\
\text { for cooking } \\
(5)\end{array}$ & $\begin{array}{c}\text { Fossil fuels } \\
\text { for cooking } \\
(6)\end{array}$ \\
\hline \multicolumn{7}{|c|}{ Panel A. Parameter estimates } \\
\hline Remittances & & & $\begin{array}{c}-1.928^{*} \\
(1.141)\end{array}$ & $\begin{array}{l}2.683^{* * *} \\
(0.292)\end{array}$ & $\begin{array}{l}-0.260^{* *} \\
(0.127)\end{array}$ & $\begin{array}{l}0.691^{* *} \\
(0.294)\end{array}$ \\
\hline Migration & & & $\begin{array}{l}1.843^{* * *} \\
(0.143)\end{array}$ & $\begin{array}{l}-1.581^{* * *} \\
(0.264)\end{array}$ & $\begin{array}{l}0.247^{* * *} \\
(0.065)\end{array}$ & $\begin{array}{r}-0.742^{*} \\
(0.383)\end{array}$ \\
\hline $\begin{array}{l}\text { Exchange rate shocks } \\
\text { (household level) }\end{array}$ & $\begin{array}{l}0.027^{* * *} \\
(0.009)\end{array}$ & $\begin{array}{l}0.081^{* * *} \\
(0.013)\end{array}$ & & & & \\
\hline Developed countries & $\begin{array}{l}0.551^{* * *} \\
(0.144)\end{array}$ & $\begin{array}{l}-0.188 \\
(0.174)\end{array}$ & & & & \\
\hline Travel time to cities & $\begin{array}{c}0.030 \\
(0.042)\end{array}$ & $\begin{array}{l}-0.072 \\
(0.083)\end{array}$ & $\begin{array}{c}0.782 \\
(2.659)\end{array}$ & $\begin{array}{c}0.991 \\
(2.309)\end{array}$ & $\begin{array}{c}1.811 \\
(1.287)\end{array}$ & $\begin{array}{l}-2.233 \\
(2.301)\end{array}$ \\
\hline Control variables $\mathbf{W}$ and $\mathbf{X}$ & Yes & Yes & Yes & Yes & Yes & Yes \\
\hline \multicolumn{7}{|l|}{ Panel B. Test and fit statistics } \\
\hline $\begin{array}{l}\text { Instrument } F \text {-test } \\
(p \text {-value })\end{array}$ & $\begin{array}{l}41.6^{* * *} \\
(<.0001)\end{array}$ & $\begin{array}{l}16.5^{* * *} \\
(<.0001)\end{array}$ & & & & \\
\hline $\begin{array}{l}\text { Wu-Hausman test } \\
\text { ( } p \text {-value) }\end{array}$ & & & $\begin{array}{l}3.640 \\
(0.162)\end{array}$ & $\begin{array}{c}2.300 \\
(0.316)\end{array}$ & $\begin{array}{c}0.070 \\
(0.966)\end{array}$ & $\begin{array}{c}0.520 \\
(0.770)\end{array}$ \\
\hline$R^{2}$ & 0.261 & 0.207 & & & & \\
\hline
\end{tabular}

Note: The sample includes 3,721 households. Normalized household weights are applied to the estimation of all the models. Standard error is in parentheses except the two test statistics reported in Panel B where associated $p$-value is in parentheses. *,**, and *** indicate statistical significance at the 10,5 , and $1 \%$ levels, respectively. 


\section{Footnotes}

${ }^{1}$ If we combined the last two rounds of NLSS, for example, the panel sample of NLSS 2010/11 consists 100 wards visited by NLSS 2003/04. Fifty of them were taken from the cross-sectional component of NLSS 2003/04, and the remaining fifty from the panel component of NLSS 2003/04 which were visited by NLSS 1995/96. The cross-sectional and the panel components, however, were sampled separately and thus cannot be simply combined. This would reduce the usable sample from 326 wards to a maximum of 50.

${ }^{2}$ In rare cases (e.g., large urban wards in metropolitan areas), the segments of the wards were selected as PSUs. This segmentation is not a concern for our study because most of the segments were removed from the sample due to their little forest cover. Thus, it is safely assumed that PSU is equivalent to ward based on our discussion with the CBS officers.

${ }^{3}$ Statistical matching techniques such as the propensity scoring method are not appropriate here. Of 281 sampled wards, households from 266 wards (treatment group) received remittances, leading to a very small control group with only 15 wards. The significant difference in the sample size between the treatment and the control groups makes it difficult to pair the treated and control units.

${ }^{4}$ A standard practice in the literature to abate the potential endogeneity of a weight variable is to construct it using the number of migrants in the previous period, e.g., extracting relevant variables from the first round of NLSS 1995/96 in the case of Nepal. But adopting this strategy would cause new problems because (i) the structure of remittance source had changed significantly from 1995/96 to 2003/04 (for example, the total share of remittances within Nepal and from India decreased from $77 \%$ in $1995 / 96$ to $47 \%$ in $2003 / 04$ ), and (ii) only 100 wards from 
NLSS 1995/96 were revisited by NLSS 2003/04. Using the lagged weight variable would greatly reduce our sample size.

${ }^{5}$ The NLSS reports migration and household absentees in two distinct sections. Double counting is not a concern. Our examination of the migrants' characteristics such as gender, age, and location indicates that it is rarely the case that a migrant sent remittances to multiple household members multiple times during the last 12 months prior to the survey interview.

${ }^{6}$ In the first-stage migration equation, the significantly positive coefficient estimate of the household-level exchange rate shocks arises from the manner in which exchange rate shocks is created. In the NLSS 2003/04, about $69 \%$ of households did not receive remittances and the exchange rate shocks for these households are assigned zero. The large share of zeros is strongly correlated with the zeros in the migration variable, as presented in column 2 of Tables 5 and 6. This result is in sharp contrast to the ward-level analysis in which only $5 \%$ of wards did not receive remittances. As a robustness check, we replaced the household-level exchange rate shocks with the ward-level exchange rate shocks in the household-level migration equation and found its coefficient estimate remaining statistically insignificant. 